\title{
PENGARUH PROFESIONALISME, PENGETAHUAN MENDETEKSI KEKELIRUAN, DAN ETIKA PROFESI TERHADAP PERTIMBANGAN TINGKAT MATERIALITAS AKUNTAN PUBLIK
}

\author{
Marini \\ Universitas Pamulang \\ Dosen01975@unpam.ac.id
}

\begin{abstract}
Relevance and reliability are the two primary qualities that make accounting information useful for decision making. Therefore, an audit of financial statement is necessary, especially for a Tbk company. To maintain the trust of clients and users of financial statements, the public accountants should to have sufficient competence, such as professionalism, knowledge to detects errors, professional ethics and judgement of materiality level. Purpose of this study is to provide empirical evidence about affect of professionalism, knowledge to detect errors, and professional ethics to the public accountants judgement of materiality level with partial and simultaneous. Population in the study is a public accountant who worked at a Public Accounting Firm in South Jakarta. Sampling technique using convenience sampling method. Data obtained by questionnaire survey completed by the public accountant with 98 respondents from 9 Public Accounting Firm with primary data types. Design is causal research. The results showed that : 1) Professionalism affect of the judgement of materiality level. 2) Knowledge to detect errors did not affect of the judgement of materiality level. 3) Professional ethics affect of the judgement of materiality level. 4) Professionalism, knowledge to detect errors, and professional ethics affect of the judgement of materiality level.
\end{abstract}

Keyword : Professionalism, Knowledge to detect errors, Professional ethics and Judgment of materiality level.

\section{PENDAHULUAN}

Audit atas laporan keuangan sangat diperlukan terutama bagi perusahaan yang berbadan hukum berbentuk perseroan terbatas yang bersifat terbuka. Laporan keuangan perusahaan telah menjadi sebuah media komunikasi yang diperlukan pihak-pihak di luar perusahaan yang berkepentingan untuk dijadikan dasar pengambilan keputusan.

Semakin meluasnya kebutuhan jasa profesional akuntan publik sebagai pihak yang dianggap independen, menuntut profesi akuntan publik untuk 
meningkatkan kinerjanya agar dapat menghasilkan produk audit yang dapat diandalkan bagi pihak yang membutuhkan. Untuk dapat meningkatkan sikap profesionalisme dalam melaksanakan audit atas laporan keuangan, hendaknya para akuntan publik memiliki pengetahuan audit yang memadai serta dilengkapi dengan pemahaman mengenai kode etik profesi.

Akuntan publik harus meningkatkan kinerjanya agar dapat menghasilkan produk audit yang dapat diandalkan bagi pihak yang membutuhkan. Guna peningkatan kinerja, hendaknya akuntan publik memiliki sikap profesional dalam melaksanakan audit atas laporan keuangan. Dengan profesionalisme yang tinggi, kebebasan akuntan publik akan terjamin.

Setiap akuntan publik juga diharapkan memiliki pengetahuan yang memadai dalam profesinya untuk mendukung pekerjaannya dalam melakukan setiap pemeriksaan. Akuntan yang lebih berpengalaman akan bertambah pengetahuannya dalam melakukan proses audit khususnya dalam mendeteksi kekeliruan. Pengetahuan akuntan publik dapat diperoleh dari berbagai pelatihan formal maupun dari pengalaman khusus.

Seorang akuntan publik juga harus memegang teguh etika profesi yang sudah ditetapkan oleh Ikatan Akuntan Indonesia (IAI), agar situasi persaingan tidak sehat dapat dihindarkan. Di Indonesia, etika akuntan menjadi isu yang sangat menarik. Hal ini seiring dengan terjadinya beberapa pelanggaran etika yang dilakukan oleh akuntan, baik akuntan independen, akuntan intern perusahaan maupun akuntan pemerintah. Tanpa etika, profesi akuntansi tidak akan ada karena fungsi akuntansi adalah penyedia informasi untuk proses pembuatan keputusan bisnis oleh para pelaku bisnis. Di samping itu, profesi akuntan mendapat sorotan yang cukup tajam dari masyarakat.

Pertimbangan akuntan publik tentang materialitas adalah suatu masalah kebijakan profesional dan dipengaruhi oleh persepsi akuntan publik tentang kebutuhan yang beralasan dari laporan keuangan. Materialitas pada tingkat laporan keuangan adalah besarnya keseluruhan salah saji minimum dalam suatu laporan keuangan yang cukup penting sehingga membuat laporan keuangan menjadi tidak disajikan secara wajar sesuai dengan prinsip-prinsip akuntansi yang berlaku umum. 
Tingkat materialitas suatu laporan keuangan tidak akan sama tergantung pada ukuran laporan keuangan tersebut.

Fenomena audit yang terjadi di Indonesia antara lain pada tahun 2005, diduga terjadi manipulasi data dalam laporan keuangan PT. Kereta Api Indonesia, perusahaan BUMN itu dicatat meraih keuntungan sebesar Rp 6,9 miliar. Padahal apabila diteliti dan dikaji lebih rinci, perusahaan seharusnya menderita kerugian sebesar Rp 63 miliar.

Berdasarkan uraian di atas, maka peneliti tertarik untuk mengambil judul "Pengaruh Profesionalisme, Pengetahuan Mendeteksi Kekeliruan, dan Etika Profesi terhadap Pertimbangan Tingkat Materialitas Akuntan Publik". Penelitian ini merupakan replikasi dari penelitian yang telah dilakukan oleh Herawaty dan Susanto (2009).

Pokok permasalahan dalam penelitian ini akan dirumuskan sebagai berikut : (a) apakah profesionalisme, pengetahuan mendeteksi kekeliruan, dan etika profesi berpengaruh terhadap pertimbangan tingkat materialitas akuntan publik secara parsial? dan (b) apakah profesionalisme, pengetahuan mendeteksi kekeliruan, dan etika profesi berpengaruh terhadap pertimbangan tingkat materialitas akuntan publik secara simultan?

\section{TELAAH LITERATUR DAN PENGEMBANGAN HIPOTESIS}

\section{Auditing}

Secara umum definisi auditing menurut Mulyadi (2002:9) adalah sebagai berikut :

Auditing adalah suatu proses sistematik untuk memperoleh dan mengevaluasi bukti secara objektif mengenai pernyataan-pernyataan tentang kegiatan dan kejadian ekonomi, dengan tujuan untuk menetapkan tingkat kesesuaian antara pernyataanpernyataan tersebut dengan kriteria yang telah ditetapkan, serta penyampaian hasilhasilnya kepada pemakai yang berkepentingan.

Menurut Arens, dkk (2003:15) definisi auditing adalah sebagai berikut : 
Pengumpulan serta pengevaluasian bukti-bukti atas informasi untuk menentukan dan melaporkan tingkat kesesuaian informasi tersebut dengan kriteria-kriteria yang telah ditetapkan. Auditing harus dilaksanakan oleh seseorang yang kompeten dan independen.

\section{Standar Auditing}

Standar auditing merupakan pedoman audit atas laporan keuangan historis. Standar ini terdiri dari sepuluh standar dan dirinci dalam bentuk Pernyataan Standar Auditing (PSA).

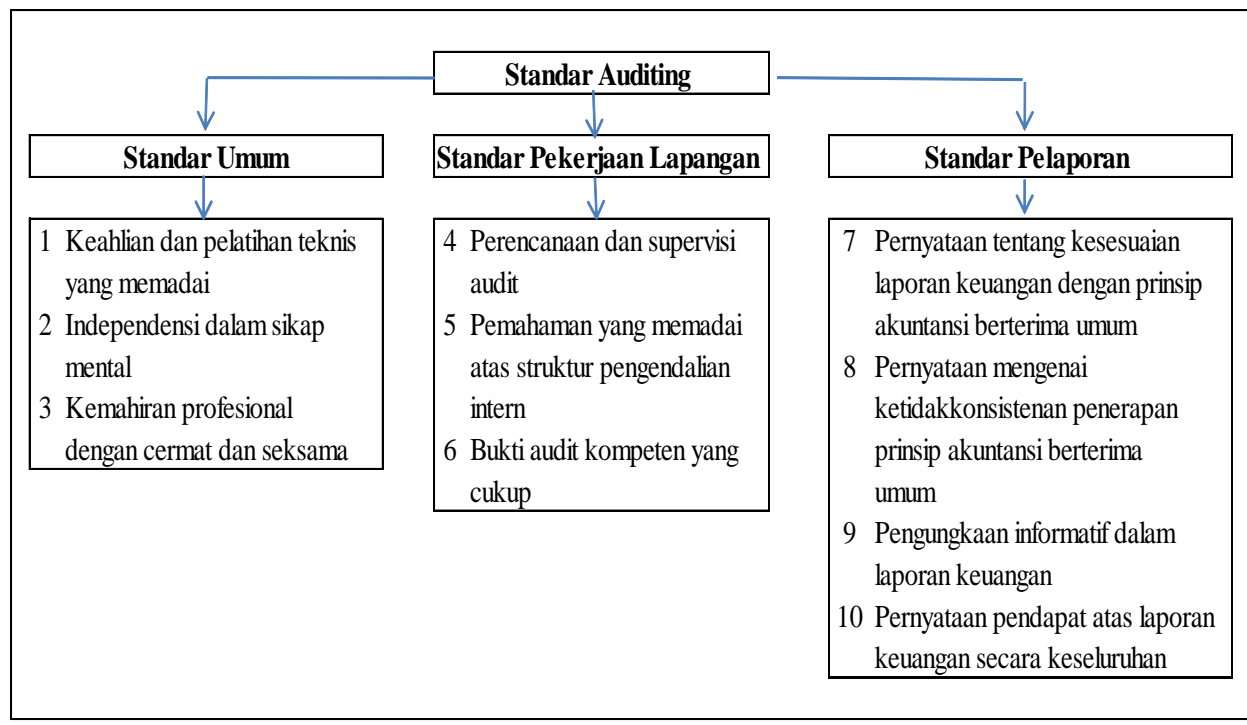

Sumber : Mulyadi (2002)

Gambar 1

Hierarki Standar Auditing

\section{Profesionalisme}

Profesi dan profesionalisme dapat dibedakan secara konseptual. Profesi merupakan jenis pekerjaan yang memenuhi beberapa kriteria, sedangkan profesionalisme adalah suatu atribut individual yang penting tanpa melihat suatu pekerjaan merupakan suatu profesi atau tidak.

Menurut Kamus Besar Bahasa Indonesia : Profesi adalah pekerjaan dimana dari pekerjaan tersebut diperoleh nafkah untuk hidup, sedangkan profesionalisme 
dapat diartikan bersifat profesi atau memiliki keahlian dan keterampilan karena pendidikan dan latihan.

Secara sederhana, profesionalisme berarti bahwa akuntan publik wajib melaksanakan tugas-tugasnya dengan kesungguhan dan kecermatan. Sebagai seorang yang profesional, akuntan publik harus menghindari kelalaian dan ketidakjujuran. Arens dkk (2003) mendefinisikan profesionalisme sebagai "tanggung jawab individu untuk berperilaku yang lebih baik dari sekedar mematuhi undang-undang dan peraturan masyarakat yang ada”. Profesionalisme juga merupakan elemen dari motivasi yang memberikan sumbangan pada seseorang agar mempunyai kinerja tugas yang tinggi.

\section{Konsep Profesionalisme}

Menurut Hall (1968) dalam Herawati dan Susanto (2009) terdapat lima dimensi profesionalisme, yaitu :

a. Pengabdian pada profesi

Pengabdian pada profesi dicerminkan dari dedikasi profesionalisme dengan menggunakan pengetahuan dan kecakapan yang dimiliki. Keteguhan untuk tetap melaksanakan pekerjaan meskipun imbalan ekstrinsik kurang. Sikap ini adalah ekspresi dari pencurahan diri yang total terhadap pekerjaan. Pekerjaan didefinisikan sebagai tujuan, bukan hanya alat untuk mencapai tujuan. Totalitas ini sudah menjadi komitmen pribadi, sehingga kompensasi utama yang diharapkan dari pekerjaan adalah kepuasan rohani, baru kemudian materi.

b. Kewajiban sosial

Kewajiban sosial adalah pandangan tentang pentingnya peranan profesi dan manfaat yang diperoleh baik masyarakat maupun profesional karena adanya pekerjaan tersebut.

c. Kemandirian

Kemandirian dimaksudkan sebagai suatu pandangan seseorang yang profesional harus mampu membuat keputusan sendiri tanpa tekanan dari pihak lain (pemerintah, klien, dan bukan anggota profesi). Setiap ada campur tangan dari luar dianggap sebagai hambatan kemandirian secara profesional. 
d. Keyakinan terhadap peraturan profesi

Keyakinan terhadap profesi adalah suatu keyakinan bahwa yang paling berwenang menilai pekerjaan profesional adalah rekan sesama profesi, bukan orang luar yang tidak mempunyai kompetensi dalam bidang ilmu dan pekerjaan mereka.

e. Hubungan dengan sesama profesi

Hubungan dengan sesama profesi adalah menggunakan ikatan profesi sebagai acuan, termasuk didalamnya organisasi formal dan kelompok kolega informal sebagai ide utama dalam pekerjaan. Melalui ikatan profesi ini para profesional membangun kesadaran profesional.

\section{Pengetahuan Mendeteksi Kekeliruan}

Pengetahuan adalah suatu fakta atau kondisi mengetahui sesuatu dengan baik yang didapat lewat pengalaman dan pelatihan. Adapun definisi lain dari pengetahuan yaitu segala maklumat yang berguna bagi tugas yang akan dilakukan. Definisi pengetahuan menurut ruang lingkup audit adalah kemampuan penguasaan auditor atau akuntan pemeriksa terhadap medan audit (penganalisaan laporan keuangan perusahaan).

Mendeteksi adalah usaha akuntan publik untuk menjelaskan kekurangwajaran laporan keuangan yang disajikan oleh perusahaan melalui identifikasi berbagai kekeliruan dan kecurangan serta membuktikan kekeliruan dan kecurangan tersebut dalam pos-pos laporan keuangan perusahaan.

Menurut Arens dan Loebbecke (1997) dalam Andre Sucipto (2007), kekeliruan atau misstatement adalah "salah saji dalam laporan keuangan". Ada dua jenis kekeliruan yaitu :

a. Error adalah kekeliruan yang tidak disengaja dalam laporan keuangan

b. Fraud adalah kekeliruan yang disengaja atau kecurangan dalam laporan keuangan

Pengertian mengenai kekeliruan menurut Ikatan Akuntan Indonesia (IAI) dalam Standar Profesional Akuntan Publik (SPAP) paragraf 6, dinyatakan bahwa : 
Kekeliruan (error) berarti salah saji (misstatement) atau hilangnya jumlah atau pengungkapan dalam laporan keuangan yang tidak disengaja. Kekeliruan dapat berupa:

a. Kekeliruan dalam pengumpulan atau pengolahan data yang menjadi sumber penyusunan laporan keuangan.

b. Estimasi akuntansi yang tidak masuk akal yang timbul dari kecerobohan atau salah tafsir fakta.

c. Kekeliruan dalam penerapan prinsip akuntansi yang berkaitan dengan jumlah, klasifikasi, dan cara penyajian atau pengungkapan.

Kekeliruan meliputi salah saji perhitungan atau penulisan dalam catatan dan data akuntansi yang menjadi dasar penyusunan laporan keuangan, kesalahan dalam penerapan prinsip akuntansi serta keterlewatan dan kesalahan dalam penafsiran fakta yang ada saat laporan keuangan disusun. Rencana pemeriksaan akuntan publik yang sesuai norma pemeriksaan akuntansi akan memperhitungkan kemungkinan adanya kekeliruan dan kecurangan yang cukup material.

Menurut SPAP (IAI, 2001) ada dua tipe salah saji yang relevan dengan pertimbangan tingkat akuntan publik tentang kecurangan dalam audit atas laporan keuangan :

a. Salah saji yang timbul dari kecurangan dalam pelaporan keuangan adalah salah saji atau penghilangan secara sengaja jumlah atau pengungkapan dalam laporan keuangan untuk mengelabuhi pemakai laporan keuangan. Kecurangan dalam laporan keuangan dapat menyangkut tindakan seperti yang disajikan berikut ini :

1) Manipulasi, pemalsuan, atau perubahan catatan akuntansi atau dokumen pendukungnya yang menjadi sumber data bagi penyajian laporan keuangan.

2) Representasi yang salah dalam atau penghilangan dari laporan keuangan peristiwa, transaksi, atau informasi signifikan.

3) Salah penerapan secara sengaja prinsip akuntansi yang berkaitan dengan jumlah, klasifikasi, cara penyajian, atau pengungkapan.

b. Salah saji yang timbul dari perlakuan tidak semestinya terhadap aktiva (seringkali disebut dengan penyalahgunaan atau penggelapan) berkaitan dengan pencurian aktiva entitas yang berakibat laporan keuangan tidak disajikan sesuai 
dengan prinsip akuntansi yang berlaku umum di Indonesia. Perlakuan tidak semestinya terhadap aktiva entitas dapat dilakukan dengan berbagai cara, termasuk penggelapan tanda terima barang atau uang, pencurian aktiva, atau tindakan yang menyebabkan entitas membayar harga barang atau jasa yang tidak diterima oleh entitas. Perlakuan tidak semestinya terhadap aktiva dapat disertai dengan catatan atau dokumen palsu atau yang menyesatkan dan dapat menyangkut satu atau lebih individu diantara manajemen, karyawan, atau pihak ketiga.

\section{Jenis Kekeliruan}

Dalam pengauditan terdapat banyak jenis kekeliruan yang umumnya terjadi, Richard M. Tubbs (1992) dalam penelitian Sri Sularso dan Ainun Naim (1999) telah mengidentifikasikan 41 macam jenis kekeliruan yang umumnya terjadi pada saat pengauditan, pencatatan penjualan dalam jurnal penjualan, posting piutang dagang ke buku besar pembantu umum, penerimaan kas dalam jurnal penerimaan kas, posting penerimaan kas pada buku besar pembantu piutang. Macam dan jenis kekeliruan menurut Richard M. Tubbs (1992) dalam penelitian Sri Sularso dan Ainun Naim (1999) adalah :

1) Pesanan diterima dan barang dikirim kepada pelanggan yang risiko kreditnya jelek atau tidak sah

2) Pesanan diterima dengan syarat selain yang disahkan manajemen

3) Spesifikasi pesanan tidak dipenuhi dalam hal jenis dan kuantitasnya

4) Pemberian kredit yang berlebihan dan tidak benar dengan pengaturan pembayaran kembali

5) Penentuan harga dan perkaliannya tidak benar dengan pengaturan pembayaran kembali

6) Manajemen, pegawai, atau pihak ketiga menerima produk atau jasa tanpa ditagih atau ditagih dengan pengurangan harga yang tidak sah

7) Pelanggan dikenakan tagihan dengan jumlah uang yang tidak benar

8) Analisa umur piutang tidak benar, jumlah piutang yang secara potensial tidak terkumpul tidak diakui kekeliruan dalam pencatatan penjualan dalam jurnal penjualan 
9) Tidak dicatat (dikirim tanpa diberi faktur)

10) Salah jumlah uangnya

11) Salah periode (waktu) nya

12) Salah dalam posting penjualan/piutang dagang ke buku besar umum

13) Penjualan fiktif

14) Lalai mencatat penerimaan piutang yang telah dihapus kekeliruan posting piutang dagang ke buku besar umum

15) Salah jumlah uangnya

16) Salah periode (waktu) nya

17) Salah rekening

18) Tidak diposting

19) Diposting dua kali

20) Uang tunai atau cek hilang

21) Penerimaan kas tidak didepositokan tepat waktu Kekeliruan pencatatan penerimaan kas dalam jurnal penerimaan kas

22) Tidak dicatat

23) Dicatat dua kali

24) Salah jumlah uangnya

25) Salah periode (waktu) nya

26) Penerimaan kas dicatat sebagai penjualan tunai bukan penerimaan piutang

27) Uang hasil angsuran/tagihan piutang diselewengkan kekeliruan posting penerimaan kas pada buku besar pembantu piutang

28) Tidak dipostingkan

29) Salah jumlah uangnya

30) Salah rekening

31) Salah periode (waktu) nya

32) Lapping

33) Rekening dihapus secara tidak benar untuk menutupi penyelewengan penerimaan kas

34) Retur atau bentuk keringanan lain digolongkan keliru atau tidak dicatat

35) Retur tidak dicatat dalam periode yang tepat 
36) Pelaporan lebih terhadap pendapatan dengan cara penerimaan retur atau jaminan

37) Keliru perhitungan dalam menghitung saldo piutang

38) Perhitungan PPN Keluaran salah

39) Piutang kepada perusahaan afiliasi lebih besar dan tidak lancar tertagihnya

40) Manipulasi PPN Keluaran

41) Manipulasi (mark up) L/C

Pengetahuan akuntan publik dapat diperoleh dari berbagai pelatihan formal maupun dari pengalaman khusus, berupa kegiatan seminar, lokakarya, serta pengarahan dari auditor senior kepada auditor juniornya. Pengetahuan juga dapat diperoleh dari frekuensi seorang akuntan publik yang melakukan pekerjaan dalam proses audit laporan keuangan. Seseorang yang melakukan pekerjaan sesuai dengan pengetahuan yang dimilikinya akan memberikan hasil yang lebih baik daripada mereka yang tidak memiliki pengetahuan yang cukup memadai akan tugasnya.

Pengetahuan akuntan publik digunakan sebagai salah satu kunci keefektifan kerja. Akuntan yang memiliki pengetahuan dan keahlian secara profesional dapat meningkatkan pengetahuan tentang sebab dan konsekuensi kekeliruan dalam suatu siklus akuntansi. Pengetahuan akuntan publik tentang pendeteksian kekeliruan semakin berkembang karena pengalaman kerja.

\section{Etika Profesi}

Etika secara umum didefinisikan sebagai serangkaian prinsip atau nilai-nilai moral atau aturan-aturan tingkah laku yang diterima dan digunakan oleh suatu golongan tertentu atau individu.

Setiap profesi yang menyediakan jasanya kepada masyarakat memerlukan kepercayaan dari masyarakat yang dilayaninya. Kepercayaan masyarakat terhadap mutu jasa akuntan publik akan menjadi lebih tinggi jika profesi tersebut menerapkan standar mutu tinggi terhadap pelaksanaan pekerjaan profesional yang dilakukan oleh anggota profesinya. 


\section{Kode Etik Ikatan Akuntan Indonesia}

Kode etik profesional didefinisikan sebagai pedoman bagi para anggota IAI untuk bertugas secara bertanggung jawab dan objektif. Tujuan Kode Etik Profesional adalah sebagai berikut :

a. Dengan adanya kode etik akan mengikat para anggota profesi pada nilai-nilai sosial tertentu yang memungkinkan manusia hidup produktif baik di bidang ekonomi, sosial dan kultural sesuai martabat manusiawi sebagaimana dituntut perkembangan jaman.

b. Dengan adanya kode etik akan mengikat pula para anggota profesi pada suatu bentuk disiplin untuk mengejar dan berbakti kepada nilai-nilai yang diakui lebih tinggi, dengan demikian etika profesional harus diarahkan pada nilai-nilai sosial yang lebih tinggi dan bukan ditujukan kepada pembuktian untuk kepentingan kelompok profesional yang bersangkutan.

Tiga alasan pentingnya Kode Etik Profesional yaitu :

a. Memberikan referensi secara eksplisit mengatur secara kriteria aturan untuk suatu profesi.

b. Memberi keputusan kepada seseorang apa yang diharapkan profesinya.

c. Dari pandangan organisasi profesi, kode etik adalah pernyataan umum aturanaturan.

\section{Materialitas}

Materialitas merupakan dasar penerapan standar auditing, terutama standar pekerjaan lapangan dan standar pelaporan. Materialitas mempunyai pengaruh yang mencakup semua aspek audit dalam audit atas laporan keuangan.

Materialitas menurut Mulyadi (2002:158) adalah sebagai berikut : Materialitas adalah besarnya nilai yang dihilangkan atau salah saji informasi akuntansi, yang dilihat dari keadaan yang melingkupinya, dapat mengakibatkan perubahan atas atau pengaruh terhadap pertimbangan orang yang meletakkan kepercayaan terhadap informasi tersebut, karena adanya penghilangan atau salah saji itu. 
Materialitas dalam akuntansi adalah sesuatu yang relatif, nilai kuantitatif yang penting dari beberapa informasi keuangan, bagi para pemakai laporan keuangan dalam konteks pembuatan keputusan.

Dua alasan mengapa konsep materialitas penting dalam audit, yaitu sebagian pemakai informasi akuntansi tidak dapat memahami informasi akuntansi dengan mudah, maka pengungkapan data penting harus dipisahkan dari data yang tidak penting, karena pengungkapan data penting yang bersamaan dengan data tidak penting cenderung menyesatkan pemakai laporan keuangan dan proses pemeriksaan akuntansi dimaksudkan untuk mendapatkan tingkat jaminan (guarantee) yang layak mengenai kewajaran penyajian laporan keuangan pada suatu waktu tertentu.

\section{Pertimbangan Awal tentang Materialitas}

Akuntan publik melakukan pertimbangan awal tentang tingkat materialitas dalam perencanaan auditnya. Penentuan materialitas ini, yang seringkali disebut dengan materialitas perencanaan, mungkin dapat berbeda dengan tingkat materialitas yang digunakan pada saat pengambilan kesimpulan audit dan dalam mengevaluasi temuan audit karena keadaan yang melingkupi berubah dan informasi tambahan tentang klien dapat diperoleh selama berlangsungnya audit.

Pertimbangan materialitas mencakup pertimbangan kuantitatif dan kualitatif. Pertimbangan kuantitatif berkaitan dengan hubungan salah saji dengan jumlah kunci tertentu dalam laporan keuangan. Pertimbangan kualitatif berkaitan dengan penyebab salah saji. Suatu salah saji yang secara kuantitatif tidak material dapat secara kualitatif material karena penyebab yang menimbulkan salah saji tersebut.

Berikut ini disajikan contoh pertimbangan kuantitatif dan kualitatif yang dilakukan oleh akuntan publik dalam mempertimbangkan materialitas.

a. Hubungan salah saji dengan jumlah kunci tertentu dalam laporan seperti :

1) Laba bersih sebelum pajak dalam laporan keuangan.

2) Total aktiva dalam neraca.

3) Total aktiva lancar dalam neraca.

4) Total ekuitas pemegang saham dalam neraca.

b. Faktor kualitatif, seperti : 
1) Kemungkinan terjadinya pembayaran yang melanggar hukum.

2) Kemungkinan terjadinya kecurangan.

3) Syarat yang tercantum dalam perjanjian penarikan kredit dari bank yang mengharuskan klien untuk mempertahankan beberapa rasio keuangan pada tingkat minimum tertentu.

4) Adanya gangguan dalam trend laba.

5) Sikap manajemen terhadap integritas laporan keuangan.

\section{Tingkatan Materialitas dalam Mempertimbangkan Jenis Laporan Audit}

Tingkatan materialitas yang sering digunakan akuntan publik dalam mempertimbangkan jenis laporan audit, seperti :

a. Jumlah Tidak Material

Jika salah saji dalam laporan keuangan dianggap "tidak material" dan cenderung tidak mempengaruhi keputusan pemakai laporan, maka jenis laporan audit dengan "pendapat wajar tanpa pengecualian" dapat dipertimbangkan akuntan publik untuk diberikan.

b. Jumlah Material Tetapi Tidak Mengganggu Laporan Keuangan Secara Keseluruhan

Jika salah saji dalam satu perkiraan tertentu dalam laporan keuangan dianggap "material" tetapi salah saji tersebut tidak mengganggu laporan keuangan secara keseluruhan namun kondisi tersebut mempengaruhi keputusan pemakai laporan, maka jenis laporan audit dengan "pendapat wajar dengan pengecualian" dapat dipertimbangkan akuntan publik untuk diberikan.

c. Jumlahnya Sangat Material dan Pengaruhnya Sangat Luas sehingga Kewajaran Laporan Keuangan Secara Keseluruhan Diragukan

Jika salah saji dalam laporan keuangan dianggap "sangat material" dan pengaruhnya sangat luas, sehingga kewajaran laporan keuangan secara keseluruhan diragukan dan dapat membuat keputusan yang salah bagi pemakai laporan, maka jenis laporan audit dengan "pendapat tidak wajar atau tidak memberikan pendapat" dapat dipertimbangkan akuntan publik untuk diberikan. 


\section{Materialitas pada Tingkat Laporan Keuangan}

Akuntan publik menggunakan dua cara dalam menetapkan materialitas yaitu dengan menggunakan materialitas dalam perencanaan audit dan pada saat mengevaluasi bukti audit dalam pelaksanaan audit. Pada saat merencanakan audit, akuntan perlu membuat estimasi materialitas karena terdapat hubungan yang terbalik antara jumlah dalam laporan keuangan yang dipandang material oleh akuntan dengan jumlah pekerjaan audit yang diperlukan untuk menyatakan kewajaran laporan keuangan.

Akuntan publik harus mempertimbangkan dengan baik penaksiran materialitas pada tahap perencanaan audit. Jika akuntan menentukan jumlah rupiah materialitas terlalu rendah, akuntan akan mengkonsumsi waktu dan usaha yang sebenarnya tidak diperlukan. Sebaliknya jika akuntan menentukan jumlah rupiah materialitas terlalu tinggi, akuntan akan mengabaikan salah saji yang signifikan sehingga memberikan pendapat wajar tanpa pengecualian untuk laporan keuangan yang sebenarnya berisi salah saji material.

Laporan keuangan mengandung salah saji material jika laporan tersebut berisi kekeliruan atau kecurangan yang dampaknya, secara individual atau secara gabungan, sedemikian signifikan sehingga mencegah penyajian secara wajar laporan keuangan tersebut sesuai dengan prinsip akuntansi berterima umum. Dalam keadaan ini, salah saji dapat terjadi sebagai akibat penerapan secara keliru prinsip akuntansi berterima umum di Indonesia, penyimpangan dari fakta, atau penghilangan informasi yang diperlukan.

Dalam perencanaan audit, akuntan harus menyadari bahwa terdapat lebih dari satu tingkat materialitas yang berkaitan dengan laporan keuangan. Kenyataannya, setiap laporan keuangan dapat memiliki lebih dari satu tingkat materialitas. Untuk laporan laba-rugi, materialitas dapat dihubungkan dengan total pendapatan, laba bersih usaha, laba bersih sebelum pajak, atau laba bersih setelah pajak. Untuk neraca, materialitas dapat didasarkan pada total aktiva, aktiva lancar, modal kerja, atau modal saham.

Dalam melakukan pertimbangan awal tentang materialitas, mula-mula akuntan menentukan tingkat materialitas gabungan untuk setiap laporan keuangan. 
Untuk tujuan perencanaan audit, akuntan harus menggunakan tingkat salah saji gabungan yang terkecil yang dianggap material terhadap salah satu laporan keuangan. Dasar pengambilan keputusan ini semestinya digunakan karena laporan keuangan adalah saling berhubungan satu dengan lainnya dan banyak prosedur audit berkaitan dengan lebih dari satu laporan keuangan.

Pertimbangan awal akuntan publik tentang materialitas seringkali dibuat 6-9 bulan sebelum tanggal neraca. Oleh karena itu, pertimbangan tersebut dapat didasarkan atas data laporan keuangan yang dibuat tahunan. Sebagai alternatif, pertimbangan tersebut dapat didasarkan atas hasil keuangan satu tahun atau lebih yang telah lalu, yang disesuaikan dengan perubahan terkini, seperti keadaan ekonomi umum dan trend industri.

\section{Materialitas pada Tingkat Saldo Akun}

Materialitas pada tingkat saldo akun adalah salah saji minimum yang mungkin terdapat dalam saldo akun yang dipandang sebagai salah saji material. Konsep materialitas pada tingkat saldo akun tidak boleh dicampur adukkan dengan istilah saldo akun material. Saldo akun material adalah besarnya saldo akun yang tercatat, sedangkan konsep materialitas berkaitan dengan jumlah salah saji yang dapat mempengaruhi keputusan pemakai informasi keuangan. Saldo suatu akun yang tercatat umumnya mencerminkan batas atas lebih saji (overstatement) dalam akun tersebut. Akun dengan saldo yang jauh lebih kecil dibandingkan dengan materialitas seringkali disebut sebagai tidak material mengenai risiko lebih saji. Namun, tidak ada batas jumlah kurang saji dalam suatu akun dengan saldo tercatat yang lebih kecil. Oleh karena itu, harus disadari oleh akuntan bahwa akun yang kelihatannya bersaldo tidak material, dapat berisi kurang saji (understatement) yang melampaui materialitasnya.

Dalam mempertimbangkan materialitas pada tingkat saldo akun, akuntan harus mempertimbangkan hubungan antara materialitas tersebut dengan materialitas laporan keuangan. Pertimbangan ini mengarahkan akuntan untuk merencanakan audit guna mendeteksi salah saji yang kemungkinan tidak material secara 
individual, namun, jika digabungkan dengan salah saji dalam saldo akun yang lain, dapat material terhadap laporan keuangan secara keseluruhan.

\section{Pengembangan Hipotesis :}

Untuk mengetahui adanya pengaruh profesionalisme, pengetahuan mendeteksi kekeliruan, dan etika profesi terhadap pertimbangan tingkat materialitas akuntan publik, maka diperlukan pengujian hipotesis dengan menggunakan uji statistik sebagai berikut :

$\mathrm{Ho}_{1}$ : Tidak terdapat pengaruh profesionalisme terhadap pertimbangan tingkat materialitas akuntan publik.

$\mathrm{Ha}_{1}$ : Terdapat pengaruh profesionalisme terhadap pertimbangan tingkat materialitas akuntan publik.

$\mathrm{Ho}_{2}$ : Tidak terdapat pengaruh pengetahuan mendeteksi kekeliruan terhadap pertimbangan tingkat materialitas akuntan publik.

$\mathrm{Ha}_{2}$ : Terdapat pengaruh pengetahuan mendeteksi kekeliruan terhadap pertimbangan tingkat materialitas akuntan publik.

$\mathrm{Ho}_{3}$ : Tidak terdapat pengaruh etika profesi terhadap pertimbangan tingkat materialitas akuntan publik.

$\mathrm{Ha}_{3}$ : Terdapat pengaruh etika profesi terhadap pertimbangan tingkat materialitas akuntan publik.

Ho4: Tidak terdapat pengaruh profesionalisme, pengetahuan mendeteksi kekeliruan, dan etika profesi terhadap pertimbangan tingkat materialitas akuntan publik.

Ha4: Terdapat pengaruh profesionalisme, pengetahuan mendeteksi kekeliruan, dan etika profesi terhadap pertimbangan tingkat materialitas akuntan publik.

\section{METODE PENELITIAN DAN PEMBAHASAN}

Desain penelitian merupakan penelitian kausal (causal research), yaitu penelitian yang bertujuan untuk mengetahui pengaruh antara satu atau lebih variabel bebas (independent variable) terhadap variabel terikat (dependent variable). 
Jenis data yang digunakan adalah data primer yaitu data yang dapat diambil dari individu atau perseorangan, seperti hasil pengisian kuesioner. Populasi untuk penelitian ini adalah semua akuntan publik yang berada di Kantor Akuntan Publik (KAP) wilayah Jakarta Selatan. Sedangkan sampel penelitian ini adalah sebagian akuntan publik (auditor junior, senior, supervisor, manajer maupun partner) yang berada di KAP wilayah Jakarta Selatan.

Metode pengambilan sampel (sampling method) yang digunakan adalah convenience sampling, yaitu metode pengambilan sampel berdasarkan pertimbangan kemudahan agar dapat diperoleh sejumlah informasi dasar secara cepat dan efisien. Convenience sampling adalah anggota populasi yang paling mudah ditemui dipilih sebagai subjek dan merupakan bagian dari non probability sampling. Kriteria responden yang dijadikan sampel dalam penelitian ini adalah sebagai berikut :

a. Pengalaman bekerja minimal satu tahun

b. Memiliki jenjang pendidikan minimal S1

c. Posisi minimal sebagai auditor junior

Variabel merupakan segala sesuatu yang akan menjadi objek pengamatan dalam penelitian yang merupakan suatu konsep yang memiliki variasi nilai.

a. Variabel bebas/independent variable (variabel X)

1) Profesionalisme $\left(X_{1}\right)$

Persyaratan profesional yang dituntut dari auditor independen adalah orang yang memiliki pendidikan dan pengalaman berpraktik sebagai auditor independen. Profesionalisme akuntan publik merupakan sikap dan perilaku akuntan dalam menjalankan profesinya dengan kesungguhan dan tanggung jawab agar mencapai kinerja tugas sebagaimana yang diatur oleh organisasi profesi.

2) Pengetahuan Mendeteksi Kekeliruan $\left(X_{2}\right)$

Penggunaan kemahiran profesional dengan cermat dan seksama memungkinkan auditor untuk memperoleh keyakinan memadai bahwa laporan keuangan bebas dari salah saji material, baik yang disebabkan oleh 
kekeliruan atau kecurangan. Akuntan yang memiliki pengetahuan dan keahlian secara profesional dapat meningkatkan pengetahuan tentang sebab dan konsekuensi kekeliruan dalam suatu siklus akuntansi.

3) Etika Profesi $\left(X_{3}\right)$

Etika profesi adalah nilai-nilai tingkah laku atau aturan-aturan tingkah laku yang diterima dan digunakan oleh organisasi profesi akuntan. Prinsip-prinsip ini terdapat dalam Kode Etik Ikatan Akuntan Indonesia yang dikeluarkan oleh IAI.

b. Variabel terikat/dependent variable (variabel Y)

Pertimbangan auditor mengenai materialitas merupakan pertimbangan profesional dan dipengaruhi oleh persepsi auditor atas kebutuhan orang yang memiliki pengetahuan memadai dan yang akan meletakkan kepercayaan terhadap laporan keuangan. Pertimbangan mengenai materialitas yang digunakan oleh auditor dihubungkan dengan keadaan sekitarnya dan mencakup pertimbangan kuantitatif dan kualitatif.

Metode pengumpulan data dalam penelitian yaitu metode penelitian kepustakaan dan metode penelitian lapangan. Teknik pengumpulan data dilakukan dengan survey di beberapa Kantor Akuntan Publik yang ada di wilayah Jakarta Selatan. Instrumen pengumpulan data berupa kuesioner yang merupakan daftar pertanyaan/pernyataan tertulis yang telah dirumuskan sebelumnya, yang akan dijawab oleh responden, biasanya dalam alternatif yang didefinisikan dengan jelas.

Skala pengukuran yang digunakan adalah skala ordinal yang memungkinkan untuk pengurutan data dari tingkat paling rendah ke tingkat paling tinggi atau sebaliknya dengan interval yang tidak harus sama, sedangkan metode pengukuran yang digunakan adalah skala likert lima point dengan rentang angka 1-5 yang memberikan gambaran sampai seberapa jauh responden melaksanakan fungsi sesuai dengan pertanyaan yang diberikan. Skala likert digunakan untuk mengukur sikap, pendapat, dan persepsi seseorang atau sekelompok orang tentang gejala sosial. 


\section{Uji Regresi Linier Berganda}

Uji regresi linier berganda atau disebut juga multiple regression analysis berguna untuk menganalisis hubungan linier antara dua variabel independen atau lebih dengan satu variabel dependen. Pengujian hipotesis ini menggunakan tingkat signifikan $($ alpha) 5\%. Jika $P$ value $(\operatorname{sig})<($ alpha $)$, maka terdapat pengaruh secara bersama-sama variabel independen terhadap variabel dependen. Persamaan regresi linier berganda dengan tiga variabel independen adalah sebagai berikut :

$$
Y=\alpha+\beta_{1} X_{1}+\beta_{2} X_{2}+\beta_{3} X_{3}+\varepsilon
$$

Peneliti menyebar kuesioner kepada 105 akuntan publik yang menjadi sampel dalam penelitian ini. Dari 105 kuesioner tersebut, terdapat 7 kuesioner yang tidak kembali. Hasil selengkapnya dapat dilihat pada tabel 1 berikut :

Tabel 1

Hasil Pengembalian Kuesioner

\begin{tabular}{|r|l|r|r|r|}
\hline No & \multicolumn{1}{|c|}{ Nama KAP } & $\begin{array}{c}\text { Kuesioner } \\
\text { yang disebar }\end{array}$ & $\begin{array}{r}\text { Kuesioner yang } \\
\text { tidak kembali }\end{array}$ & $\begin{array}{c}\text { Kuesioner } \\
\text { yang kembali }\end{array}$ \\
\hline 1 & KAP Achmad, Rasyid, Hisbullah \& Jerry & 10 & 1 & 9 \\
\hline 2 & KAP Drs. Danny Sughanda & 10 & 0 & 10 \\
\hline 3 & KAP Drs. Salam Rauf \& Rekan & 5 & 0 & 5 \\
\hline 4 & KAP Herman Dody Tanumihardja \& Rekan & 10 & 0 & 10 \\
\hline 5 & KAP Hertanto, Sidik \& Rekan & 10 & 2 & 8 \\
\hline 6 & KAP Ishak, Saleh, Soewondo \& Rekan & 10 & 0 & 10 \\
\hline 7 & KAP Noor Salim, Nursehan \& Sinarahardja & 5 & 0 & 5 \\
\hline 8 & KAP Rama Wendra & 40 & 4 & 36 \\
\hline 9 & KAP Usman \& Rekan & 5 & 0 & 5 \\
\hline & Total & 105 & 7 & 98 \\
\hline & Persentase & $100 \%$ & $7 \%$ & $93 \%$ \\
\hline
\end{tabular}

Sumber : Data yang Diolah

Tabel 1 menunjukkan bahwa partisipasi responden penelitian ini sebesar 93\%, dengan demikian dapat dilanjutkan dengan uji empiris (statistik) untuk mengukur pengaruh antara variabel independen terhadap variabel dependen. 


\section{Pengujian Instrumen Penelitian}

\section{Uji Validitas}

Validitas adalah ketepatan atau kecermatan suatu instrumen dalam pengukuran. Pada program SPSS teknik pengujian yang peneliti gunakan adalah Corrected Item-Total Correlation dengan kriteria perbandingan $\mathrm{r}$ hitung dan $\mathrm{r}$ tabel.

Uji validitas ini dilakukan dengan membandingkan nilai $r$ hitung dengan $r$ tabel untuk df = n-k-1, dimana $\mathrm{n}$ adalah jumlah data dan $\mathrm{k}$ adalah jumlah variabel independen. Dalam penelitian ini $\mathrm{df}=98-3-1$ atau $\mathrm{df}=94$ dengan $\alpha 0,05$ didapat $\mathrm{r}$ tabel sebesar 0,201. Jika $r$ hitung (per item) $>r$ tabel berarti pernyataan tersebut dikatakan valid.

a. Uji Validitas Variabel Profesionalisme

Tabel 2

Item-Total Statistics

\begin{tabular}{|c|c|c|c|}
\hline & $\begin{array}{l}\text { Corrected } \\
\text { Item-Total } \\
\text { Correlation }\end{array}$ & r tabel & Keterangan \\
\hline$X 1 \_1$ & ,499 &, 201 & Valid \\
\hline$X 1 \_2$ & ,473 &, 201 & Valid \\
\hline$\times 1 \_3$ &, 531 &, 201 & Valid \\
\hline$\times 1 \_4$ & 409 &, 201 & Valid \\
\hline$\times 1 \_5$ &, 302 &, 201 & Valid \\
\hline$\times 1 \_6$ &, 372 & 201 & Valid \\
\hline$\times 1 \_7$ &, 380 &, 201 & Valid \\
\hline$\times 1 \_8$ &, 536 & ,201 & Valid \\
\hline X1_9 &, 415 & ,201 & Valid \\
\hline$X 1 \_10$ & 447 & ,201 & Valid \\
\hline$X 1 \_11$ & 291 &, 201 & Valid \\
\hline$x 1 \_12$ & 448 & ,201 & Valid \\
\hline$X 1 \_13$ & 482 &, 201 & Valid \\
\hline$X 1 \_14$ & 297 & ,201 & Valid \\
\hline$X 1$ 15 &, 538 &, 201 & Valid \\
\hline
\end{tabular}

\section{Sumber : Output SPSS}

Berdasarkan tabel 2 pada kolom Corrected Item-Total Correlation ( $\mathrm{r}$ hitung) untuk masing-masing item atau butir pernyataan nilainya > $\mathrm{r}$ tabel 0,201, sehingga dapat disimpulkan bahwa 15 pernyataan untuk variabel profesionalisme adalah valid.

b. Uji Validitas Variabel Pengetahuan Mendeteksi Kekeliruan 
Tabel 3

Item-Total Statistics

\begin{tabular}{|c|c|c|c|}
\hline & $\begin{array}{l}\text { Corrected } \\
\text { Item-Total } \\
\text { Correlation }\end{array}$ & r tabel & Keterangan \\
\hline$\times 2 \ldots 1$ &, 364 & .201 & Valid \\
\hline$\times 2-2$ & 494 & 201 & Valid \\
\hline$\times 2-3$ & ,479 &, 201 & Valid \\
\hline$\times 2-4$ &, 789 &, 201 & Valid \\
\hline$\times 2 \_5$ &, 865 & 201 & Valid \\
\hline$\times 2 \_6$ &, 853 &, 201 & Valid \\
\hline$\times 2-7$ & 859 &, 201 & Valid \\
\hline$\times 2-8$ &, 827 &, 201 & Valid \\
\hline$\times 2 \_9$ &, 863 & 201 & Valid \\
\hline$\times 2-10$ &, 830 &, 201 & Valid \\
\hline$\times 2 \_11$ &, 876 &, 201 & Valid \\
\hline$\times 2-12$ &, 810 &, 201 & Valid \\
\hline$\times 2-13$ &, 863 & 201 & Valid \\
\hline$\times 2-14$ &, 865 &, 201 & Valid \\
\hline$\times 2-15$ &, 730 &, 201 & Valid \\
\hline$\times 2-16$ &, 717 &, 201 & Valid \\
\hline$\times 2-17$ &, 883 & 201 & Valid \\
\hline$\times 2-18$ &, 852 &, 201 & Valid \\
\hline$\times 2 \_19$ &, 792 &, 201 & Valid \\
\hline$\times 2 \_20$ &, 848 &, 201 & Valid \\
\hline$\times 2 \_21$ &, 794 &, 201 & Valid \\
\hline$\times 2-22$ &, 842 &, 201 & Valid \\
\hline
\end{tabular}

\section{Sumber : Output SPSS}

Berdasarkan tabel 3 pada kolom Corrected Item-Total Correlation (r hitung) untuk masing-masing item atau butir pernyataan nilainya $>\mathrm{r}$ tabel 0,201, sehingga dapat disimpulkan bahwa 22 pernyataan untuk variabel pengetahuan mendeteksi kekeliruan adalah valid.

c. Uji Validitas Variabel Etika Profesi

Tabel 4

Item-Total Statistics

\begin{tabular}{|l|r|r|r|}
\hline & $\begin{array}{r}\text { Corrected } \\
\text { Item-Total } \\
\text { Correlation }\end{array}$ & r tabel & Keterangan \\
\hline X3_1 &, 315 &, 201 & Valid \\
X3_2 &, 298 &, 201 & Valid \\
X3_3 &, 391 &, 201 & Valid \\
X3_4 &, 478 &, 201 & Valid \\
X3_5 &, 325 &, 201 & Valid \\
X3_6 &, 464 &, 201 & Valid \\
X3_7 &, 545 &, 201 & Valid \\
X3_8 &, 432 &, 201 & Valid \\
X3_9 &, 619 &, 201 & Valid \\
X3_11 &, 495 &, 201 & Valid \\
X3_12 &, 438 &, 201 & Valid \\
X3_13 &, 416 &, 201 & Valid \\
\hline
\end{tabular}

Sumber : Output SPSS

Berdasarkan tabel 4 pada kolom Corrected Item-Total Correlation hanya terdapat 12 pernyataan yang valid dari 13 pernyataan variabel etika profesi, 
sehingga terdapat 1 pernyataan yang tidak valid yaitu pernyataan X3_10. Pernyataan tersebut tidak valid karena $\mathrm{r}$ hitung $<\mathrm{r}$ tabel yaitu $-0,135<0,201$, sehingga untuk butir pernyataan tersebut dikeluarkan (removed) dari instrumen pernyataan. Sedangkan $r$ hitung untuk masing-masing item atau butir pernyataan lain nilainya > r tabel, sehingga dapat disimpulkan bahwa 12 pernyataan untuk variabel etika profesi adalah valid.

d. Uji Validitas Variabel Pertimbangan Tingkat Materialitas

Tabel 5

Item-Total Statistics

\begin{tabular}{|l|r|r|r|}
\hline & $\begin{array}{r}\text { Corrected } \\
\text { Item-Total } \\
\text { Correlation }\end{array}$ & r tabel & Keterangan \\
\hline Y_1 &, 607 &, 201 & Valid \\
Y_2 &, 592 &, 201 & Valid \\
Y_3 &, 356 &, 201 & Valid \\
Y_4 &, 456 &, 201 & Valid \\
Y_5 &, 559 &, 201 & Valid \\
Y_6 &, 485 &, 201 & Valid \\
Y_7 &, 580 &, 201 & Valid \\
Y_8 &, 484 &, 201 & Valid \\
Y_9 &, 661 &, 201 & Valid \\
Y_10 &, 407 &, 201 & Valid \\
Y_11 &, 638 &, 201 & Valid \\
Y_12 &, 499 &, 201 & Valid \\
\hline
\end{tabular}

\section{Sumber : Output SPSS}

Berdasarkan tabel 5 pada kolom Corrected Item-Total Correlation (r hitung) untuk masing-masing item atau butir pernyataan nilainya $>\mathrm{r}$ tabel 0,201, sehingga dapat disimpulkan bahwa 12 pernyataan untuk variabel pertimbangan tingkat materialitas adalah valid.

\section{Uji Reliabilitas}

Uji reliabilitas digunakan untuk mengetahui konsistensi alat ukur, apakah alat pengukur yang digunakan dapat diandalkan dan tetap konsisten jika pengukuran tersebut diulang. Peneliti akan melakukan uji reliabilitas dengan teknik Cronbach 
Alpha. Suatu konstruk dikatakan reliable apabila memberikan nilai Cronbach's Alpha $\geq 0,60$.

a. Uji Reliabilitas Variabel Profesionalisme

Tabel 6

Reliability Statistics

\begin{tabular}{|r|r|}
\hline $\begin{array}{c}\text { Cronbach's } \\
\text { Alpha }\end{array}$ & $\begin{array}{c}\text { N of } \\
\text { Items }\end{array}$ \\
\hline, 808 & 15 \\
\hline
\end{tabular}

Sumber : Output SPSS

Tabel 6 menunjukkan Cronbach's Alpha 0,808 $\geq 0,60$. Dapat disimpulkan bahwa pernyataan-pernyataan dalam variabel profesionalisme adalah reliable, artinya bahwa hasil pengukuran variabel profesionalisme adalah konsisten dan andal.

b. Uji Reliabilitas Variabel Pengetahuan Mendeteksi Kekeliruan

Tabel 7

Reliability Statistics

\begin{tabular}{|r|r|}
\hline $\begin{array}{c}\text { Cronbach's } \\
\text { Alpha }\end{array}$ & $\begin{array}{c}\text { N of } \\
\text { Items }\end{array}$ \\
\hline, 973 & 22 \\
\hline
\end{tabular}

Sumber : Output SPSS

Tabel 7 menunjukkan Cronbach's Alpha 0,973 $\geq 0$,60. Dapat disimpulkan bahwa pernyataan-pernyataan dalam variabel pengetahuan mendeteksi kekeliruan adalah reliable, artinya bahwa hasil pengukuran variabel pengetahuan mendeteksi kekeliruan adalah konsisten dan andal.

c. Uji Reliabilitas Variabel Etika Profesi 
Tabel 8

\section{Reliability Statistics}

\begin{tabular}{|r|c|}
\hline $\begin{array}{c}\text { Cronbach's } \\
\text { Alpha }\end{array}$ & $\begin{array}{c}\text { N of } \\
\text { Items }\end{array}$ \\
\hline, 715 & 13 \\
\hline
\end{tabular}

\section{Sumber : Output SPSS}

Tabel 8 menunjukkan Cronbach's Alpha 0,715 $\geq 0,60$. Dapat disimpulkan bahwa pernyataan-pernyataan dalam variabel etika profesi adalah reliable, artinya bahwa hasil pengukuran variabel etika profesi adalah konsisten dan andal.

d. Uji Reliabilitas Variabel Pertimbangan Tingkat Materialitas

Tabel 9

\section{Reliability Statistics}

\begin{tabular}{|r|r|}
\hline $\begin{array}{c}\text { Cronbach's } \\
\text { Alpha }\end{array}$ & $\begin{array}{c}\text { N of } \\
\text { Items }\end{array}$ \\
\hline, 850 & 12 \\
\hline
\end{tabular}

\section{Sumber : Output SPSS}

Tabel 9 menunjukkan Cronbach's Alpha 0,850 $\geq 0,60$. Dapat disimpulkan bahwa pernyataan-pernyataan dalam variabel pertimbangan tingkat materialitas adalah reliable, artinya bahwa hasil pengukuran variabel pertimbangan tingkat materialitas adalah konsisten dan andal.

\section{Uji Asumsi Klasik}

Tujuan uji asumsi klasik adalah agar data yang digunakan layak dijadikan sumber pengujian dan dapat dihasilkan kesimpulan yang benar. Uji asumsi klasik meliputi :

\section{Uji Normalitas}

Uji normalitas dimaksudkan untuk memperlihatkan bahwa sampel diambil dari populasi yang berdistribusi normal. Peneliti menggunakan uji KolmogorovSmirnov untuk mengetahui apakah sampel berasal dari populasi yang berdistribusi normal. Normalitas dapat diketahui dengan melihat tabel One-Sample Kolmogorov- 
Smirnov Test pada kolom Asymp.Sig. (2-tailed) yaitu jika p value (Sig.) > 0,05 maka dapat disimpulkan bahwa data diambil dari populasi terdistribusi normal.

Tabel 10

\begin{tabular}{|c|c|c|c|c|c|}
\hline \multicolumn{6}{|c|}{ One-Sample Kolmogorov-Smirnov Test } \\
\hline & & Profesionalisme & $\begin{array}{c}\text { Pengetahuan } \\
\text { Mendeteksi } \\
\text { Kekeliruan }\end{array}$ & $\begin{array}{l}\text { Etika } \\
\text { Profesi }\end{array}$ & $\begin{array}{c}\text { Pertimbangan } \\
\text { Tingkat } \\
\text { Materialitas }\end{array}$ \\
\hline \multicolumn{2}{|l|}{$\mathrm{N}$} & 98 & 98 & 98 & 98 \\
\hline Normal & Mean & 750,0009 & 1099,9994 & 600,0020 & 600,0022 \\
\hline Parameters ${ }^{\mathrm{a}, \mathrm{b}}$ & Std. Deviation & 79,43358 & 175,52171 & 69,37044 & 74,54475 \\
\hline \multirow{3}{*}{$\begin{array}{l}\text { Most Extreme } \\
\text { Differences }\end{array}$} & Absolute &, 114 & ,112 & ,129 & ,118 \\
\hline & Positive &, 114 &, 112 &, 129 &, 118 \\
\hline & Negative &,- 057 &,- 089 &,- 061 &,- 092 \\
\hline \multicolumn{2}{|c|}{ Kolmogorov-Smirnov Z } & 1,126 & 1,113 & 1,279 & 1,168 \\
\hline \multicolumn{2}{|c|}{ Asymp. Sig. (2-tailed) } &, 158 &, 168 &, 076 &, 130 \\
\hline
\end{tabular}

Dari tabel 10 diperoleh hasil Asymp. Sig. (2-tailed) untuk variable Profesionalisme $=0,158>0,05$, Pengetahuan Mendeteksi Kekeliruan $=0,168>$ 0,05, Etika Profesi $=0,076>0,05$ dan Pertimbangan Tingkat Materialitas $=0,130>$ 0,05 , maka dapat disimpulkan data yang diambil dari populasi berdistribusi normal.

\section{Uji Multikolinearitas}

Multikolinearitas artinya antarvariabel independen yang terdapat dalam model regresi memiliki hubungan linear yang sempurna atau mendekati sempurna (koefisien korelasinya tinggi atau bahkan 1). Model regresi yang baik seharusnya tidak terjadi korelasi sempurna atau mendekati sempurna diantara variabel bebasnya. Variabel yang menyebabkan multikolinearitas dapat dilihat dari nilai tolerance $<0,1$ atau nilai VIF (Variance Inflation Factor) $>10$. 
Tabel 11

\begin{tabular}{|c|c|c|}
\hline \multicolumn{3}{|l|}{ Coefficients $^{\text {a }}$} \\
\hline \multirow[t]{2}{*}{ Model } & \multicolumn{2}{|c|}{$\begin{array}{l}\text { Collinearity } \\
\text { Statistics }\end{array}$} \\
\hline & Tolerance & VIF \\
\hline Profesionalisme &, 678 & 1,474 \\
\hline 1 Pengetahuan Mendeteksi Kekeliruan & ,974 & 1,026 \\
\hline Etika Profesi & ,668 & 1,498 \\
\hline
\end{tabular}

a. Dependent Variable: Pertimbangan Tingkat Materialitas

\section{Sumber : Output SPSS}

Dari tabel 11 dapat diketahui bahwa nilai variance inflation factor (VIF) variabel profesionalisme, pengetahuan mendeteksi kekeliruan dan etika profesi $<10$, dan nilai tolerance > 0,1 sehingga dapat disimpulkan bahwa antar variabel independen tidak terjadi persoalan multikolinearitas.

\section{Uji Heteroskedastisitas}

Heteroskedastisitas adalah varian residual yang tidak sama pada semua pengamatan di dalam model regresi. Regresi yang baik seharusnya tidak terjadi heteroskedastisitas. Peneliti melakukan uji heteroskedastisitas dengan melihat pola titik-titik pada grafik regresi. Kriteria yang menjadi dasar pengambilan keputusan adalah sebagai berikut :

1) Jika ada pola tertentu, seperti titik-titik yang ada membentuk suatu pola tertentu yang teratur (bergelombang, melebar, kemudian menyempit), maka terjadi heteroskedastisitas.

2) Jika tidak ada pola yang jelas, seperti titik-titik menyebar di atas dan di bawah angka 0 pada sumbu Y, maka tidak terjadi heteroskedastisitas.

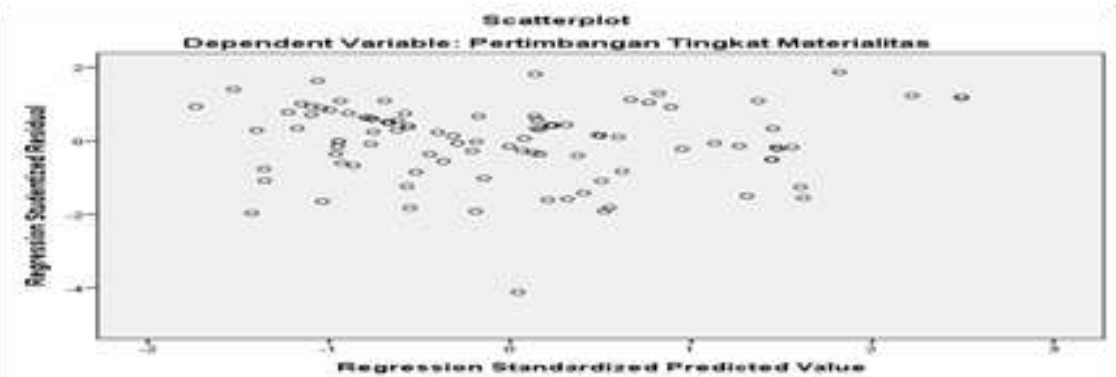

Sumber : Output SPSS

Gambar 2

Scatterplot 
Dari gambar 2 dapat diketahui bahwa titik-titik tidak membentuk pola yang jelas. Sebagaimana terlihat, titik-titik itu menyebar di atas dan di bawah angka 0 pada sumbu Y. Jadi, dapat disimpulkan bahwa tidak terjadi heteroskedastisitas dalam model regresi.

\section{Uji Autokorelasi}

Autokolerasi merupakan korelasi antara anggota observasi yang disusun menurut waktu dan tempat. Autokorelasi biasanya terjadi apabila pengukuran variabel dilakukan dalam interval waktu tertentu. Deteksi autokolerasi dilakukan dengan uji statistik Durbin-Watson. Autokolerasi tidak terjadi apabila nilai d $=2$. Autokorelasi positif terjadi jika d mendekati 0, sedangkan autokorelasi negatif terjadi bila nilai d mendekati 4 .

Tabel 12

\section{Model Summary ${ }^{\mathrm{b}}$}

\begin{tabular}{|l|c|r|r|r|r|}
\hline Model & R & R Square & $\begin{array}{r}\text { Adjusted } \\
\text { R Square }\end{array}$ & $\begin{array}{r}\text { Std. Error of } \\
\text { the Estimate }\end{array}$ & $\begin{array}{r}\text { Durbin- } \\
\text { Watson }\end{array}$ \\
\hline 1 &, $720^{\mathrm{a}}$ &, 518 &, 503 & 52,55638 & 2,005 \\
\hline
\end{tabular}
a. Predictors: (Constant), Etika Profesi, Pengetahuan
Mendeteksi Kekeliruan, Profesionalisme
b. Dependent Variable: Pertimbangan Tingkat Materialitas

Sumber : Output SPSS

Dari tabel 12 didapatkan nilai statistik uji Durbin-Watson sebesar 2,005 (mendekati 2). Dengan demikian dapat disimpulkan bahwa tidak terjadi masalah autokolerasi antara variabel bebas dengan variabel terikat.

\section{Uji Korelasi}

Uji Korelasi Pearson (Product Moment Pearson) berguna untuk mengukur keeratan hubungan antara variabel profesionalisme, pengetahuan mendeteksi kekeliruan, etika profesi, dan pertimbangan tingkat materialitas yang memiliki distribusi data normal. Pengujian signifikansi dengan dua sisi (two tailed) untuk 
mengetahui apakah terdapat hubungan signifikan atau tidak diantara variabelvariabel tersebut.

Tabel 13

Correlations

\begin{tabular}{|ll|r|r|r|r|}
\hline & & Profesionalisme & $\begin{array}{r}\text { Pengetahuan } \\
\text { Mendeteksi } \\
\text { Kekeliruan }\end{array}$ & $\begin{array}{c}\text { Etika } \\
\text { Profesi }\end{array}$ & $\begin{array}{c}\text { Pertimbangan } \\
\text { Tingkat } \\
\text { Materialitas }\end{array}$ \\
\hline Profesionalisme & Pig. (2-tailed) & 1 &,- 100 &, 567 &, $632^{* * *}$ \\
& $\mathrm{~N}$ & &, 325 &, 000 &, 000 \\
Pengetahuan & Pearson Correlation &,- 100 & 98 & 98 & 98 \\
Mendeteksi & Sig. (2-tailed) & 1 &,- 159 &, 002 \\
Kekeliruan & $\mathrm{N}$ & 925 & &, 117 &, 985 \\
& Pearson Correlation &, $567^{* *}$ &,- 159 & 98 & 98 \\
Etika Profesi & Sig. (2-tailed) &, 000 &, 117 & &, $628^{* * *}$ \\
& $\mathrm{~N}$ & 98 & 98 & 98 &, 000 \\
Pertimbangan & Pearson Correlation &, $632^{* *}$ &, 002 &, $628^{* *}$ & 98 \\
Tingkat & Sig. (2-tailed) &, 000 &, 985 &, 000 & 1 \\
Materialitas & $\mathrm{N}$ & 98 & 98 & 98 & 98 \\
\hline
\end{tabular}

**. Correlation is significant at the 0.01 level (2-tailed).

\section{Sumber : Output SPSS}

\section{Uji Hipotesis}

Untuk mengetahui ada tidaknya pengaruh antara variabel dependen dan independen secara parsial dan simultan dapat dilakukan dengan menggunakan hasil output SPSS sebagai berikut :

a. Uji Hipotesis Secara Parsial (uji t)

Untuk mengetahui variabel independen apakah berpengaruh secara signifikan atau tidak terhadap variabel dependen dapat dilakukan dengan membandingkan $\mathrm{t}$ hitung dengan $\mathrm{t}$ tabel, jika $\mathrm{t}$ hitung $>\mathrm{t}$ tabel maka dapat disimpulkan terdapat pengaruh antara variabel independen dengan variabel dependen atau sebaliknya jika $\mathrm{t}$ hitung $<\mathrm{t}$ tabel maka tidak terdapat pengaruh antara variabel independen terhadap variabel dependen.

T tabel dapat dilihat pada tabel statistik pada signifikansi $0,05 / 2=0,025$ dengan derajat kebebasan $(\mathrm{df})=\mathrm{n}-\mathrm{k}-1=98-3-1=94$. Hasil yang diperoleh 
untuk t tabel sebesar 1,986, sedangkan t hitung dapat dilihat dari hasil output SPSS pada tabel Coefficients sebagai berikut :

\section{Tabel 14}

\begin{tabular}{|c|c|c|c|c|c|c|c|}
\hline \multirow{3}{*}{ Model } & \multicolumn{5}{|c|}{ Coefficients ${ }^{a}$} & & \\
\hline & \multicolumn{2}{|c|}{$\begin{array}{c}\text { Unstandardized } \\
\text { Coefficients }\end{array}$} & \multirow{2}{*}{$\begin{array}{c}\begin{array}{c}\text { Standardized } \\
\text { Coefficients }\end{array} \\
\text { Beta }\end{array}$} & \multirow[t]{2}{*}{$\mathrm{t}$} & \multirow[t]{2}{*}{ Sig. } & \multicolumn{2}{|c|}{$\begin{array}{c}\text { Collinearity } \\
\text { Statistics }\end{array}$} \\
\hline & $\mathrm{B}$ & $\begin{array}{l}\text { Std. } \\
\text { Error }\end{array}$ & & & & Tolerance & VIF \\
\hline (Constant) & $-5,150$ & 68,997 & &,- 075 & ,941 & & \\
\hline Profesionalisme & ,383 & ,082 & ,408 & 4,695 &, 000 & ,678 & 1,474 \\
\hline 1 Pengetahuan &, 046 & ,031 &, 109 & 1,503 &, 136 & ,974 & 1,026 \\
\hline $\begin{array}{l}\text { Mendeteksi } \\
\text { Kekeliruan }\end{array}$ & & & & & & & \\
\hline Etika Profesi & , 445 & ,094 & ,414 & 4,727 & ,000 & 668 & 1,498 \\
\hline
\end{tabular}

\section{Sumber : Output SPSS}

Berdasarkan tabel 14, selanjutnya dilakukan pengujian hipotesis secara parsial (uji t) masing-masing variabel penelitian yaitu sebagai berikut :

1) Profesionalisme terhadap Pertimbangan Tingkat Materialitas

Pada tabel 14 diperoleh nilai $\mathrm{t}$ hitung variabel profesionalisme sebesar 4,695 > t tabel 1,986 dan tingkat signifikansi $0,000<0,05$, maka $\mathrm{Ho}_{1}$ ditolak dan $\mathrm{Ha}_{1}$ diterima, artinya bahwa profesionalisme berpengaruh secara signifikan terhadap pertimbangan tingkat materialitas. Artinya, semakin profesional seorang akuntan publik maka pertimbangan tingkat materialitas dalam laporan keuangan akan semakin tepat.

Keprofesionalan dalam sebuah pekerjaan sangat penting. Hal ini dikarenakan profesionalitas berhubungan dengan kebutuhan akan kepercayaan publik terhadap kualitas jasa yang diberikan profesi. Begitu halnya dengan seorang akuntan publik, penting untuk meyakinkan klien dan pemakai laporan keuangan akan kualitas auditnya dalam hal ini yang berhubungan dengan pertimbangan terhadap tingkat materialitas laporan keuangan. Jika pemakai jasa tidak memiliki keyakinan pada akuntan dalam mempertimbangkan tingkat materialitas, maka kemampuan para profesional itu untuk memberikan jasa kepada klien dan masyarakat secara efektif akan berkurang. 
2) Pengetahuan Mendeteksi Kekeliruan terhadap Pertimbangan Tingkat Materialitas

Pada tabel 14 diperoleh t hitung variabel pengetahuan mendeteksi kekeliruan sebesar 1,503 < t tabel 1,986 dan tingkat signifikansi 0,136> 0,05, maka $\mathrm{Ho}_{2}$ diterima dan $\mathrm{Ha}_{2}$ ditolak, artinya bahwa pengetahuan mendeteksi kekeliruan tidak berpengaruh secara signifikan terhadap pertimbangan tingkat materialitas. Artinya, baik buruknya suatu pertimbangan tingkat materialitas tidak ditentukan oleh tingkat pengetahuan dari akuntan publik dalam mendeteksi kekeliruan.

Keadaan ini didukung dari beberapa fakta yang berhubungan dengan responden dalam penelitian yang dilakukan. Pertama, dilihat dari lama kerja akuntan publik dalam melaksanakan audit, dimana 64,3\% akuntan publik yang menjadi responden dalam penelitian memiliki lama kerja antara 1-3 tahun sehingga para akuntan publik belum benar-benar memahami pengetahuan dalam hal pendeteksian kekeliruan maupun penentuan pertimbangan tingkat materialitas. Kedua, akuntan publik yang menjadi responden dalam penelitian sebagian besar merupakan auditor junior $(65,3 \%)$ sehingga pengalaman audit yang dimilikinya masih terbatas. Hal ini tentu saja berpengaruh dalam pengisian jawaban pernyataan didalam kuesioner yang disebar oleh peneliti terutama dalam variabel pengetahuan mendeteksi kekeliruan.

Selain beberapa hal diatas, pengetahuan mendeteksi kekeliruan tidak berpengaruh terhadap pertimbangan tingkat materialitas juga akibat dari tidak cermatnya seorang akuntan publik dalam menggunakan kemahiran profesionalnya. Hal ini sering terjadi pada Kantor Akuntan Publik (KAP) non big four atau KAP yang kecil, dimana orientasi atau tujuan yang utama adalah mendapatkan klien sebanyak mungkin sehingga dalam hal ini KAP menggunakan segala cara untuk mendapatkan banyak klien termasuk dengan menghiraukan penggunaan kemahiran profesional bagi akuntan publik, misalnya melakukan kerjasama dalam penentuan tingkat materialitas agar pendapat laporan akuntan dapat disesuaikan dengan apa yang diinginkan 
oleh klien, hal ini tentunya tidak menunjukan seorang auditor yang seharusnya menggunakan kemahiran profesional dalam pelaksanaan audit.

3) Etika Profesi terhadap Pertimbangan Tingkat Materialitas

Pada tabel 14 diperoleh t hitung variabel etika profesi sebesar 4,727 > $\mathrm{t}$ tabel 1,986 dan tingkat signifikansi $0,000<0,05$, maka $\mathrm{Ho}_{3}$ ditolak dan $\mathrm{Ha}_{3}$ diterima, artinya bahwa etika profesi berpengaruh secara signifikan terhadap pertimbangan tingkat materialitas. Artinya, semakin tinggi etika yang dimiliki oleh seorang akuntan publik maka semakin berkualitas pertimbangan materialitas yang dilakukan oleh akuntan publik tersebut.

Setiap akuntan publik diharapkan memegang teguh etika profesi yang sudah ditetapkan oleh Institut Akuntan Publik Indonesia, agar persaingan tidak sehat dapat dihindarkan. Tanpa etika, profesi akuntansi tidak akan ada karena fungsi akuntansi adalah penyedia informasi untuk proses pembuatan keputusan bisnis oleh para pelaku bisnis. Dengan menjunjung tinggi etika profesi diharapkan tidak terjadi kecurangan diantara para akuntan publik, sehingga dapat memberikan pendapat auditan yang benar-benar sesuai dengan laporan keuangan yang disajikan oleh perusahaan.

b. Uji Hipotesis Secara Simultan (Uji F)

Uji $\mathrm{F}$ digunakan untuk mengetahui ada tidaknya pengaruh secara bersama-sama (simultan) variabel bebas terhadap variabel terikat. Uji $F$ dilakukan dengan cara membandingkan $\mathrm{F}$ hitung dan $\mathrm{F}$ tabel dimana $\mathrm{F}$ hitung diperoleh dari hasil Output SPSS dalam Anova.

F tabel diperoleh dari tabel statistik dengan tingkat signifikansi 0,05 dengan df 1 ( pembilang) $=$ jumlah variabel- $1=4-1=3$ dan df 2 (penyebut) $=$ $\mathrm{n}-\mathrm{k}-1=98-3-1=94$. Hasil yang diperoleh untuk F tabel sebesar 2,701.

Tabel 15

\begin{tabular}{|c|c|c|c|c|c|}
\hline \multicolumn{6}{|c|}{ ANOVAa } \\
\hline Model & Sum of Squares & df & $\begin{array}{c}\text { Mean } \\
\text { Square }\end{array}$ & $\bar{F}$ & Sig. \\
\hline $\begin{array}{ll} & \text { Regression } \\
1 & \begin{array}{l}\text { Residual } \\
\text { Total }\end{array} \\
\end{array}$ & $\begin{array}{l}279376,952 \\
259644,285 \\
539021,237\end{array}$ & $\begin{array}{r}3 \\
94 \\
97\end{array}$ & $\begin{array}{r}93125,651 \\
2762,173\end{array}$ & 33,715 &, $\mathrm{OOO}^{\mathrm{b}}$ \\
\hline
\end{tabular}

Sumber : Output SPSS 
Berdasarkan tabel 15 dapat disimpulkan bahwa hasil $F$ hitung sebesar 33,715 > F tabel 2,701 dan tingkat signifikansi 0,000 < 0,05. Dengan demikian Ho4 ditolak dan Ha4 diterima, artinya profesionalisme, pengetahuan mendeteksi kekeliruan dan etika profesi berpengaruh secara simultan terhadap pertimbangan tingkat materialitas. Dengan demikian maka semakin tinggi tingkat profesionalisme, pengetahuan mendeteksi kekeliruan dan etika profesi maka pertimbangan tingkat materialitas akan semakin baik.

Dalam rangka meningkatkan kualitas jasa audit, dalam hal ini pertimbangan tingkat materialitas, akuntan publik harus selalu mengikuti perkembangan peraturan, hukum maupun kasus-kasus yang terjadi di dalam ataupun di luar negeri. Aturan-aturan tentang pelaksanaan akuntan publik terdapat dalam kode etik profesi akuntan yang dikeluarkan oleh Institut Akuntan Publik Indonesia (IAPI). Seorang akuntan publik yang memiliki tingkat profesionalisme yang tinggi tentu akan semakin taat terhadap kode etik profesi karena akuntan publik menganggap jika pelaksanaan audit yang dilakukan tidak sesuai dengan kode etik maka hasil audit tersebut tidak layak dikatakan sebagai hasil audit yang andal dan tidak dapat dijadikan sumber untuk pengambilan keputusan oleh pemakai informasi akuntansi. Pengetahuan akuntan publik juga digunakan sebagai salah satu kunci keefektifan kerja. Dalam audit, pengetahuan tentang barmacam-macam pola yang berhubungan dengan kemungkinan kekeliruan dalam laporan keuangan penting untuk membuat perencanaan audit yang efektif. Seorang akuntan publik yang memiliki banyak pengetahuan tentang kekeliruan akan lebih ahli dalam melaksanakan tugasnya terutama yang berhubungan dengan pengungkapan kekeliruan. Dengan demikian dapat dikatakan bahwa semakin tinggi tingkat profesionalisme dan pengetahuan akuntan publik dalam mendeteksi kekeliruan maka semakin tinggi pula ketaatan akuntan publik terhadap kode etik profesi sehingga pertimbangan tingkat materialitas yang dilakukan akan semakin baik.

Untuk mengetahui besarnya pengaruh variabel independen terhadap variabel dependen dapat dilihat dari tabel 16 sebagai berikut : 
Tabel 16

Model Summary ${ }^{b}$

\begin{tabular}{|l|c|r|r|r|r|}
\hline Model & R & R Square & $\begin{array}{l}\text { Adjusted } \\
\text { R Square }\end{array}$ & $\begin{array}{l}\text { Std. Error of } \\
\text { the Estimate }\end{array}$ & $\begin{array}{r}\text { Durbin- } \\
\text { Watson }\end{array}$ \\
\hline 1 &, $720^{\mathrm{a}}$ &, 518 &, 503 & 52,55638 & 2,005 \\
\hline
\end{tabular}

a. Predictors: (Constant), Etika Profesi, Pengetahuan

Mendeteksi Kekeliruan, Profesionalisme

b. Dependent Variable: Pertimbangan Tingkat Materialitas

\section{Sumber : Output SPSS}

Tabel 16 menunjukkan R square sebesar 0,518, artinya profesionalisme, pengetahuan mendeteksi kekeliruan dan etika profesi berpengaruh signifikan terhadap pertimbangan tingkat materialitas akuntan publik sebesar $51,80 \%$, sedangkan sisanya sebesar 48,20\% dipengaruhi oleh variabel lain di luar model penelitian. Hasil penelitian ini dapat diinterpretasikan bahwa profesionalisme, pengetahuan mendeteksi kekeliruan dan etika profesi memiliki korelasi terhadap pertimbangan tingkat materialitas secara simultan sebesar $51,80 \%$.

\section{Uji Regresi Linier Berganda}

Tabel 17

\begin{tabular}{|c|c|c|c|c|c|c|c|}
\hline \multicolumn{8}{|c|}{ Coefficients $^{a}$} \\
\hline \multirow[t]{2}{*}{ Model } & \multicolumn{2}{|c|}{$\begin{array}{c}\text { Unstandardized } \\
\text { Coefficients }\end{array}$} & $\begin{array}{c}\text { Standardized } \\
\text { Coefficients }\end{array}$ & \multirow[t]{2}{*}{$\mathrm{t}$} & \multirow[t]{2}{*}{ Sig. } & \multicolumn{2}{|c|}{$\begin{array}{c}\text { Collinearity } \\
\text { Statistics }\end{array}$} \\
\hline & B & $\begin{array}{l}\text { Std. } \\
\text { Error }\end{array}$ & Beta & & & Tolerance & VIF \\
\hline (Constant) & $-5,150$ & 68,997 & &,- 075 & ,941 & & \\
\hline Profesionalisme &, 383 & ,082 & ,408 & 4,695 & , OOO & ,678 & 1,474 \\
\hline $1 \begin{array}{l}\text { Pengetahuan } \\
\text { Mendeteksi } \\
\text { Kekeliruan }\end{array}$ & ,046 & ,031 &, 109 & 1,503 &, 136 & ,974 & 1,026 \\
\hline Etika Profesi & ,445 & ,094 &, 414 & 4,727 &, 000 & ,668 & 1,498 \\
\hline
\end{tabular}

Sumber : Output SPSS

Dari tabel 17 dapat diketahui model persamaan regresi linier berganda sebagai berikut :

$$
Y=-5,150+0,408 X_{1}+0,109 X_{2}+0,414 X_{3}+\varepsilon
$$




\section{SIMPULAN}

Berdasarkan hasil dan analisis pengujian dapat ditarik kesimpulan sebagai berikut :

a. Profesionalisme berpengaruh terhadap pertimbangan tingkat materialitas.

b. Pengetahuan mendeteksi kekeliruan tidak berpengaruh terhadap pertimbangan tingkat materialitas.

c. Etika profesi berpengaruh terhadap pertimbangan tingkat materialitas.

d. Profesionalisme, pengetahuan mendeteksi kekeliruan dan etika profesi berpengaruh terhadap pertimbangan tingkat materialitas.

\section{Keterbatasan Penelitian}

Tidak dapat dipungkiri bahwa masih terdapat keterbatasan-keterbatasan dalam penelitian ini. Beberapa keterbatasan antara lain sebagai berikut:

a. Penelitian ini hanya menggunakan tiga variabel independen yaitu profesionalisme, pengetahuan mendeteksi kekeliruan dan etika profesi, sehingga belum dapat menghasilkan kesimpulan yang menyeluruh terhadap pertimbangan tingkat materialitas.

b. Penelitian ini menggunakan pemilihan sampel dengan teknik convenience sampling karena kemudahan dalam mendapatkan sampel sehingga kurang mempresentasikan populasi.

c. Jumlah sampel yang relatif sedikit sebesar 98 responden, hal ini dikarenakan ruang lingkup penelitian hanya pada 9 (sembilan) KAP yang ada di wilayah Jakarta Selatan. Dengan demikian, data yang diperoleh dibatasi oleh jumlah dan stratifikasi responden berdasarkan wilayah pengamatan, sehingga hasil penelitian tidak dapat digeneralisir untuk mewakili seluruh akuntan publik di Indonesia.

d. Penggunaan metode survey dalam penyebaran kuesioner sebagai instrumen penelitian yang tidak menggunakan wawancara atau observasi langsung sehingga tidak menggali secara dalam jawaban dari responden. 


\section{DAFTAR PUSTAKA}

Andre Sucipto. (2007. Analisis Pengaruh Pengetahuan dan Pengalaman Terhadap Kemampuan Akuntan Pemeriksa dalam Mendeteksi Kekeliruan Pada Kantor Akuntan Publik di Surabaya, Universitas Kristen Petra, Surabaya.

Arens, A.A., RJ. Elder, M.S. Beasley. (2001). Auditing and Assurance ServicesAn Integrated Approach, Tim Dejacarta, Edisi 9, 2003, Indeks, Jakarta.

Arleen Herawaty dan Yulius Kurnia Susanto. (2009). Pengaruh Profesionalisme, Pengetahuan Mendeteksi Kekeliruan, dan Etika Profesi Terhadap Pertimbangan Tingkat Materialitas Akuntan Publik, Jurnal Akuntansi dan Auditing Indonesia, Vol 13, No. 2 : Halaman 211-220.

C. Trihendradi. (2010). Step by Step SPSS 18 Analisis Data Statistik, Penerbit Andi, Yogyakarta.

Departemen Pendidikan Nasional. (2008). Kamus Besar Bahasa Indonesia, Edisi Keempat, Balai Pustaka, Jakarta.

Desiana. (2012). Pengaruh Profesionalisme, Pengetahuan Mendeteksi Kekeliruan, dan Etika Profesi Terhadap Pertimbangan Tingkat Materialitas oleh Auditor Pada KAP di Surabaya, Berkala Ilmiah Mahasiswa Akuntansi, Vol 1, No. 1 : Halaman 38-41.

Duwi Priyatno. (2008). 5 Jam Belajar Olah Data dengan SPSS 17, Penerbit Andi, Yogyakarta.

Ikatan Akuntan Indonesia. (2001). Standar Profesionalisme Akuntan Publik, Salemba Empat, Jakarta.

Joko Sulistyo. (2012). 6 Hari Jago SPSS 17, Penerbit Cakrawala, Yogyakarta.

Jonathan Sawono. (2013). Model-Model Linier dan Non-Linier dalam IBM SPSS 21, Elex Media Komputindo, Jakarta.

Mulyadi. (2002). Auditing, Salemba Empat, Jakarta.

Novanda Friska Bayu Aji Kusuma. (2012). Pengaruh Profesionalisme Auditor, Etika Profesi dan Pengalaman Auditor Terhadap Pertimbangan Tingkat Materialitas, Universitas Negeri Yogyakarta, Yogyakarta.

Noviyani, P. dan Bandi. (2002). Pengaruh Pengalaman dan Penelitian terhadap Struktur Pengetahuan Auditor tentang Kekeliruan, Prosiding Simposium Nasional Akuntansi $V$ : Halaman 481-488.

Reza Minanda dan Dul Muid. (2013). Analisis Pengaruh Profesionalisme, Pengetahuan Mendeteksi Kekeliruan, Pengalaman Bekerja Auditor, dan Etika Profesi Terhadap Pertimbangan Tingkat Materialitas Akuntan Publik (Studi Empiris Pada Auditor KAP di Semarang), Diponegoro Journal of Accounting, Vol 1, No. 1 : Halaman 1-8.

Sri Sularso dan Ainun Naim. (1999). Analisis Pengaruh Pengalaman Akuntan pada Pengetahuan dan Penggunaan Intuisi dalam Mendeteksi Kekeliruan, Jurnal Riset Akuntansi Indonesia, Vol 2, No. 2 : Halaman 154-172.

Taufik Hidayat dan Nina Istiadah. (2011). Panduan Lengkap Menguasai SPSS 19 untuk Mengolah Data Statistik Penelitian, Edu Explore, Semarang. 